\title{
The Cellular Prion Protein Prevents Copper-Induced Inhibition of $\mathrm{P}_{2} \mathrm{X}_{4}$ Receptors
}

\author{
Ramón A. Lorca, ${ }^{1}$ Lorena Varela-Nallar, ${ }^{2}$ \\ Nibaldo C. Inestrosa, ${ }^{2}$ and J. Pablo Huidobro-Toro ${ }^{1}$ \\ ${ }^{1}$ Departamento de Fisiología, Centro de Envejecimiento y Regeneración (CARE), Facultad de Ciencias Biológicas, \\ P. Universidad Católica de Chile, Santiago 8331150, Chile \\ ${ }^{2}$ Departamento de Biología Celular y Molecular, Centro de Envejecimiento y Regeneración (CARE), \\ Facultad de Ciencias Biológicas, P. Universidad Católica de Chile, Santiago 8331150, Chile \\ Correspondence should be addressed to Ramón A. Lorca, lorcar@wudosis.wustl.edu
}

Received 1 June 2011; Accepted 16 August 2011

Academic Editor: Rosanna Squitti

Copyright ( $) 2011$ Ramón A. Lorca et al. This is an open access article distributed under the Creative Commons Attribution License, which permits unrestricted use, distribution, and reproduction in any medium, provided the original work is properly cited.

\begin{abstract}
Although the physiological function of the cellular prion protein $\left(\mathrm{PrP}^{\mathrm{C}}\right)$ remains unknown, several evidences support the notion of its role in copper homeostasis. $\operatorname{PrP}^{\mathrm{C}}$ binds $\mathrm{Cu}^{2+}$ through a domain composed by four to five repeats of eight amino acids. Previously, we have shown that the perfusion of this domain prevents and reverses the inhibition by $\mathrm{Cu}^{2+}$ of the adenosine triphosphate (ATP)evoked currents in the $\mathrm{P}_{2} \mathrm{X}_{4}$ receptor subtype, highlighting a modulatory role for $\mathrm{PrP}^{\mathrm{C}}$ in synaptic transmission through regulation of $\mathrm{Cu}^{2+}$ levels. Here, we study the effect of full-length $\mathrm{PrP}^{\mathrm{C}}$ in $\mathrm{Cu}^{2+}$ inhibition of $\mathrm{P}_{2} \mathrm{X}_{4}$ receptor when both are coexpressed. $\mathrm{PrP}$ expression does not significantly change the ATP concentration-response curve in oocytes expressing $\mathrm{P}_{2} \mathrm{X}_{4}$ receptors. However, the presence of $\mathrm{PrP}^{\mathrm{C}}$ reduces the inhibition by $\mathrm{Cu}^{2+}$ of the ATP-elicited currents in these oocytes, confirming our previous observations with the $\mathrm{Cu}^{2+}$ binding domain. Thus, our observations suggest a role for $\mathrm{PrP}^{\mathrm{C}}$ in modulating synaptic activity through binding of extracellular $\mathrm{Cu}^{2+}$.
\end{abstract}

\section{Introduction}

Prion diseases are a group of fatal neurodegenerative disorders that are sporadic, inherited, or transmissible [1]. These include kuru and Creutzfeldt-Jakob disease in humans, scrapie in sheep and bovine spongiform encephalopathy in cattle. These pathologies are caused by the conformational transition of the native and predominantly $\alpha$-helical cellular prion protein $\left(\mathrm{PrP}^{\mathrm{C}}\right)$ into a significantly more $\beta$-sheetcontaining pathogenic isoform $\left(\mathrm{PrP}^{\mathrm{Sc}}\right)$ [2], which unlike $\mathrm{PrPC}^{\mathrm{C}}$, is insoluble in mild detergents and partially resistant to digestion with proteinase $\mathrm{K}[3] \cdot \mathrm{PrP}^{\mathrm{C}}$ is a cell surface glycosylphosphatidylinositol-anchored protein that is mainly expressed in neurons and glial cells and to a lesser extent in several peripheral tissues $[4,5]$. The normal physiological function of $\mathrm{PrP}^{\mathrm{C}}$ remains elusive, although it has been related to signaling, neuroprotection, neuritogenesis, synaptic transmission, oxidative stress, and copper metabolism [6-11].
$\mathrm{PrP}^{\mathrm{C}}$ binds copper ions with low micromolar affinity via histidine and glycine-containing peptide repeats in its $\mathrm{N}$-terminal region [12-17]. This $\mathrm{Cu}^{2+}$ binding domain is located between residues 60-91 and consists of four identical repeats of the peptide sequence Pro-His-Gly-Gly-Gly-TrpGly-Gln. Although the number of octapeptide repeats varies in different species, in mammals this region is one of the most highly conserved [18] and therefore, very likely defines a functional domain of $\mathrm{PrP}^{\mathrm{C}}$. In vitro, the octarepeat region has the capacity to reduce $\mathrm{Cu}(\mathrm{II})$ to $\mathrm{Cu}(\mathrm{I})[19,20]$. In addition, there is another $\mathrm{Cu}^{2+}$ binding site outside the octarepeat region [21-24] of higher affinity, in the order of nanomolar, that involves His96 and His111 [24]. $\mathrm{PrPC}^{\mathrm{C}}$ is localized presynaptically at central synapses [25-27] and is found in synaptic membranes and in synaptic vesicles $[9,28]$. Furthermore, $\mathrm{PrP}^{\mathrm{C}}$-null mice show an impaired long-term potentiation, suggesting that $\mathrm{PrPC}^{\mathrm{C}}$ is involved in normal synaptic function [10], and moreover, it has been shown 
that $\mathrm{PrP}^{\mathrm{C}}$ is involved in regulating the presynaptic $\mathrm{Cu}^{2+}$ concentration and synaptic transmission [9].

The P2X family of nucleotide receptors forms nonselective cationic channels activated by extracellular adenosine triphosphate (ATP) [29]. These receptors are widely expressed in the central nervous system (CNS) [30-32] and are involved in synaptic transmission and plasticity including long-term potentiation as recently shown by us [33]. Interestingly, trace metals modulate P2X receptors, particularly, the $\mathrm{P}_{2} \mathrm{X}_{4}$ receptor subtype is differentially modulated by trace metals at physiological concentrations [34-37]. While $\mathrm{Zn}^{2+}$ facilitates the ATP-evoked currents, $\mathrm{Cu}^{2+}$ inhibits it in a concentration-dependent manner [37]. Previously, we demonstrated that the N-terminal octarepeat fragment of the $\mathrm{PrP}^{\mathrm{C}}$ prevents and reverses the inhibitory action of $\mathrm{Cu}^{2+}$ on the $\mathrm{P}_{2} \mathrm{X}_{4}$ receptor when added to the media [38]. Herein, in an attempt to determine whether the $\mathrm{PrP}^{\mathrm{C}}$ $\mathrm{Cu}^{2+}$ interaction is relevant to synaptic activity, we extended our investigations to test whether the full-length $\operatorname{PrP}^{\mathrm{C}}{ }_{\mathrm{CO}}-$ expressed with the $\mathrm{P}_{2} \mathrm{X}_{4}$ receptor may modulate in situ the $\mathrm{Cu}^{2+}$-induced inhibition of the ATP current gated by the $\mathrm{P}_{2} \mathrm{X}_{4}$ receptor.

\section{Materials and Methods}

2.1. Drugs and Chemicals. Copper chloride, ATP (as the tetrasodium salt), collagenase IA, and penicillin-streptomycin were purchased from Sigma Chemical Co (St Louis, Mo). All the salts used to prepare the Barth's incubation media and the recording solutions were analytically graded and were purchased from Merck (Darmstadt, Germany).

\subsection{Oocyte Preparation, Injection, and Electrophysiological} Recordings. A segment of the Xenopus laevis ovary lobe was surgically removed from adult anesthetized frogs; stages VVI oocytes were manually defolliculated and then incubated with collagenase IA $(1 \mathrm{mg} / \mathrm{mL})$ for $30 \mathrm{~min}$. Oocytes were manually injected with 7.5-12.5 ng cDNA coding for the rat $\mathrm{P}_{2} \mathrm{X}_{4}$ receptor with or without cDNA coding for the hamster prion protein (PrP-3F4), both cDNAs in plasmid pcDNA3, at $250 \mathrm{ng} / \mu \mathrm{L}$. After $48-72 \mathrm{~h}$ of incubation at $15^{\circ} \mathrm{C}$ in Barth's solution (in $\mathrm{mM}$ ): $88 \mathrm{NaCl}, 1 \mathrm{KCl}, 2.4$ $\mathrm{NaHCO}_{3}, 10$ HEPES, $0.82 \mathrm{MgSO}_{4}, 0.33 \mathrm{Ca}\left(\mathrm{NO}_{3}\right)_{2}, \mathrm{pH}$ 7.5, supplemented with $10 \mathrm{IU} / \mathrm{L}$ penicillin/10 $\mathrm{mg}$ streptomycin, oocytes were clamped at $-70 \mathrm{mV}$ using the two-electrode voltage clamp technique with an OC-725C oocyte clamper (Warner Instrument Corp, Hamden, CT). ATP and $\mathrm{CuCl}_{2}$, dissolved in Barth's solution, were superfused at $2 \mathrm{ml} / \mathrm{min}$. ATP-evoked currents were recorded with a $10 \mathrm{~s}$ ATP exposure applied regularly at $10-15 \mathrm{~min}$ intervals. These intervals were increased up to $25 \mathrm{~min}$ for maximal ATP concentrations in concentration-response curves protocols to decrease desensitization. Copper was applied for $30 \mathrm{~s}$ prior $10 \mu \mathrm{M}$ ATP (coapplied with $\mathrm{CuCl}_{2}$ ).

2.3. Confocal Microscopy. To study the distribution of PrP, oocytes were coinjected with the cDNA coding for the rat $\mathrm{P}_{2} \mathrm{X}_{4}$ receptor with the cDNA coding for mouse PrPGFP (MmPrP-EGFP[25-266]-cDNA3). Oocytes, where P2X 4 receptor expression was validated electrophysiologically, were directly analyzed on a Zeiss LSM 5 Pascal confocal microscope.

2.4. Western Blotting. After electrophysiological protocols, each oocyte injected with cDNa coding for $\mathrm{P}_{2} \mathrm{X}_{4}$ and $\mathrm{PrP}-$ $3 \mathrm{~F} 4$ was homogenized for $30 \mathrm{~min}$ in ice, using $40 \mu \mathrm{L}$ of lysis buffer per oocyte $(100 \mathrm{mM} \mathrm{NaCl}, 20 \mathrm{mM}$ Tris- $\mathrm{HCl}$ $\mathrm{pH} 7.4,1 \%$ Triton X-100) supplemented with a protease inhibitors cocktail [39]. The extracts were centrifuged for $30 \mathrm{~s}$ at 14000 r.p.m. at $4^{\circ} \mathrm{C}$ and the supernatant was removed and resolved by 12\% SDS-PAGE and transferred to nitrocellulose. Nonspecific binding sites were blocked with $5 \%(\mathrm{w} / \mathrm{v})$ milk in Tris-Buffered Saline (TBS) $0.1 \%$ Tween (TBST) for $1 \mathrm{~h}$. After blocking, blots were incubated with monoclonal anti3F4 antibody [40], diluted $1: 5000$ in $3 \%(w / v)$ milk in TBST for $1 \mathrm{~h}$ at room temperature, followed by three $15 \mathrm{~min}$ washes in TBST at room temperature. The reactions were followed by incubation with anti-mouse antibody peroxidase labeled (Pierce, Rockford, IL) and developed by enhanced chemiluminescence.

2.5. Data Analysis. The average reduction of the ATP-gated current was normalized. The ATP and $\mathrm{Cu}^{2+}$ concentrationresponse curves were fitted to a sigmoid function using the GraphPad Prism software (San Diego, Cal). The median effective $\left(\mathrm{EC}_{50}\right)$ or median inhibitory concentrations $\left(\mathrm{IC}_{50}\right)$ for ATP or copper, respectively, were interpolated from these curves. Each protocol was performed in separate oocytes coming from at least two separate batches of oocytes. Mann-Whitney nonparametric Student's $t$-test was used for statistical analysis. A $P$ value $<0.05$ was considered significant.

\section{Results}

3.1. The Expression of PrP-3F4 Did Not Change the ATP Concentration-Response Curve of $\mathrm{P} 2 \mathrm{X}_{4}$ Receptors. To evaluate whether the expression of $\operatorname{PrPC}^{\mathrm{C}}$ modulates the inhibition of the $\mathrm{P}_{2} \mathrm{X}_{4}$ receptor by $\mathrm{Cu}^{2+}$, we first evaluated the expression of $\mathrm{PrP}^{\mathrm{C}}$ in oocytes co-injected with the cDNA coding for the hamster prion protein (PrP-3F4) and the cDNA coding for the rat $\mathrm{P} 2 \mathrm{X}_{4}$ receptor. Figure 1(a) shows the detection by western blot of $\mathrm{P}_{2} \mathrm{X}_{4}$ receptor and $\mathrm{PrP}-3 \mathrm{~F} 4$ using an antibody that recognizes the 3F4 epitope [40]. $\beta$-Tubulin detection was used as a loading control. As observed, both proteins are strongly detected in an injected oocyte and not in the control noninjected oocyte. Then we analyzed the distribution of $\mathrm{PrP}^{\mathrm{C}}$ in oocytes co-injected with the cDNA coding for the rat $\mathrm{P}_{2} \mathrm{X}_{4}$ receptor and the cDNA coding for PrP-GFP. Oocytes in which the expression of $\mathrm{P}_{2} \mathrm{X}_{4}$ receptor was verified electrophysiologically were analyzed in a confocal microscope to study the localization of PrP-GFP. As observed in Figure 1(b), PrP-GFP is located on the surface of injected oocytes.

Then, we evaluated the ATP concentration-response curves in oocytes expressing the $\mathrm{P}_{2} \mathrm{X}_{4}$ receptor and coexpressing the $\mathrm{P}_{2} \mathrm{X}_{4}$ receptor and PrP-3F4. The presence of PrP-3F4 caused a slight, but not significant, reduction in 


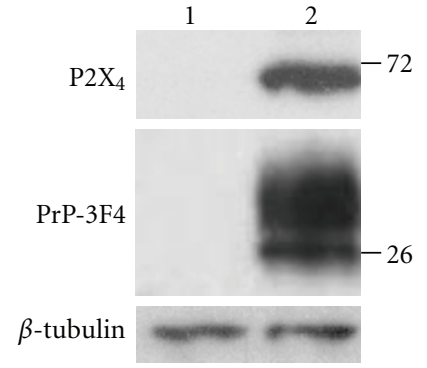

(a)

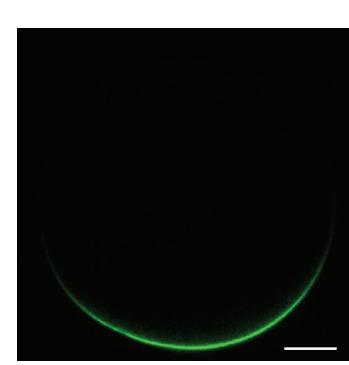

(b)
Figure 1: Coexpression of $\mathrm{P}_{2} \mathrm{X}_{4}$ and $\mathrm{PrP}^{\mathrm{C}}$ in $X$. laevis oocytes. (a) Western blot of total lysate fractions from a non-injected oocyte (left lane, 1) and from an oocyte co-expressing $\mathrm{P}_{2} \mathrm{X}_{4}$ receptor and PrP3F4 (right lane, 2). Numbers on the right are molecular weights in $\mathrm{kDa}$. (b) Fluorescence microscopy of an oocyte co-expressing $\mathrm{P}_{2} \mathrm{X}_{4}$ receptor and PrP-GFP (green), bar $=10 \mu \mathrm{M}$.

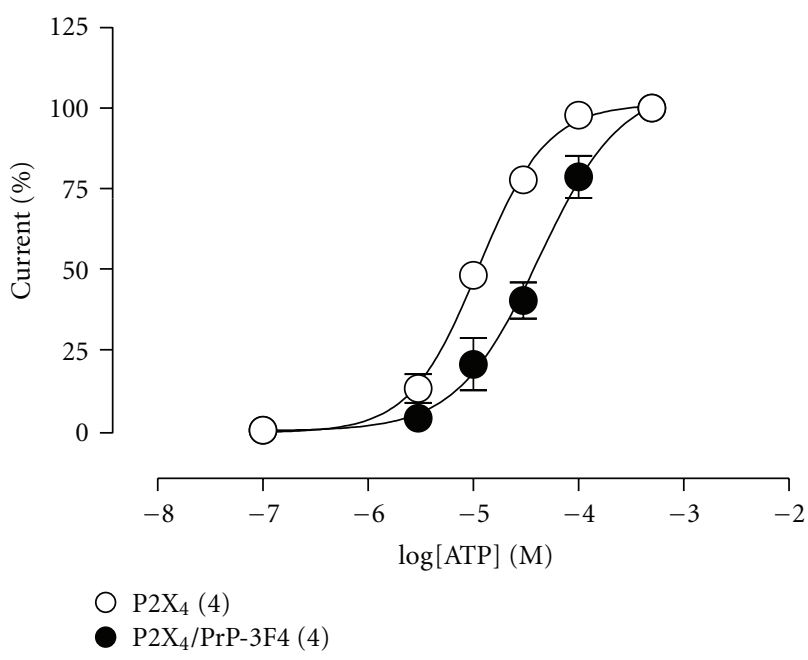

FIGURE 2: ATP concentration-response curves from oocytes expressing $\mathrm{P}_{2} \mathrm{X}_{4}$ receptor (open circles) or co-expressing $\mathrm{P}_{2} \mathrm{X}_{4}$ receptor and PrP-3F4 (closed circles). Symbols are mean values \pm SEM, numbers in parenthesis are number of oocytes.

the potency of ATP, reflected as an increase in its $\mathrm{EC}_{50}$ from $11.2 \pm 1.1 \mu \mathrm{M}$ for $\mathrm{P}_{2} \mathrm{X}_{4}$ alone to $45.2 \pm 9.4 \mu \mathrm{M}$ for $\mathrm{P}_{2} \mathrm{X}_{4} / \mathrm{PrP}-$ 3F4 ( $n=4, P=0.0571$, Figure 2 ), this slight displacement of ATP concentration-response curve in the presence of PrP$3 \mathrm{~F} 4$ could represent a minor regulation of $\mathrm{PrP}-3 \mathrm{~F} 4$ on $\mathrm{P} 2 \mathrm{X}_{4}$ receptor activity.

3.2. The Co-Expression of $\mathrm{P}_{2} \mathrm{X}_{4}$ Receptors and PrP-3F4 Partially Prevents the Copper-Induced Inhibition of the ATPEvoked Currents. We assess the $\mathrm{Cu}^{2+}$-induced inhibition of $10 \mu \mathrm{M}$ ATP currents in oocytes expressing $\mathrm{P}_{2} \mathrm{X}_{4}$ receptors. The magnitude of the inhibition by $10 \mu \mathrm{M} \mathrm{Cu}^{2+}$, preapplied during $30 \mathrm{~s}$, was $51.5 \pm 5.3 \%$ of the $10 \mu \mathrm{M}$ ATP-evoked currents $(n=14$, Figures $3(\mathrm{a})$ and $3(\mathrm{~b}))$. However, the $10 \mu \mathrm{M} \mathrm{Cu}^{2+}$-induced inhibition was reduced only to $71.9 \pm$ $5 \%$ of the $10 \mu \mathrm{M}$ ATP-evoked currents in oocytes coexpressing $\mathrm{P}_{2} \mathrm{X}_{4}$ receptors and the PrP-3F4 $(n=12, P<0.05$ compared to $\mathrm{P}_{2} \mathrm{X}_{4}$ alone, Figures 3(a) and 3(b)), showing that $\mathrm{PrP}-3 \mathrm{~F} 4$ prevented the $\mathrm{Cu}^{2+}$-induced inhibition of $\mathrm{P} 2 \mathrm{X}_{4}$ receptors compared to the $\mathrm{Cu}^{2+}$ inhibition elicited in oocytes expressing only this receptor. Furthermore, the presence of PrP-3F4 in the oocytes caused a rightward displacement of the $\mathrm{Cu}^{2+}$ concentration-response curve obtained in oocytes expressing only $\mathrm{P}_{2} \mathrm{X}_{4}$ receptor, an $\mathrm{IC}_{50}$ of $11.5 \pm 1.9 \mu \mathrm{M}$ was obtained for $\mathrm{P}_{2} \mathrm{X}_{4}$ and $34.1 \pm 7.6 \mu \mathrm{M}$ for $\mathrm{P}_{2} \mathrm{X}_{4} / \mathrm{PrP}-$ 3F4 $(n=5-7, P<0.01$, Figure 3(c)), confirming that PrP-3F4 prevented the $\mathrm{Cu}^{2+}$-induced inhibition not only at low micromolar concentrations of $\mathrm{Cu}^{2+}$, but even at higher physiological concentrations of the metal.

\section{Discussion}

Several functions have been attributed to $\mathrm{PrP}^{\mathrm{C}}$, including immunoregulation, signal transduction, copper binding, neurite outgrowth, induction of apoptosis or prevention of apoptosis against apoptotic stimuli, and others [41]. In addition, $\mathrm{PrP}^{\mathrm{C}}$ has been related to synapse formation and maintenance and synaptic transmission [9, 10, 42], although the mechanisms by which it exerts its role is still unknown. One of the proposed targets for $\mathrm{PrP}^{\mathrm{C}}$ in synapse is to modulate $\mathrm{Cu}^{2+}$ homeostasis, based on a highly conserved $\mathrm{Cu}^{2+}$-binding sequence located on its $\mathrm{N}$-terminal domain, which includes four identical repeats of the peptide sequence Pro-His-Gly-Gly-Gly-Trp-Gly-Gln $[12,15,16]$. It is known that $\mathrm{PrPC}^{\mathrm{C}}$ binds $\mathrm{Cu}^{2+}$ with high affinity [14-17], and the octarepeat region of the human $\operatorname{PrP}^{\mathrm{C}}\left(\mathrm{PrP}_{59-91}\right)$ reduces $\mathrm{Cu}(\mathrm{II})$ to $\mathrm{Cu}(\mathrm{I})$ in vitro, which depends on the tryptophan residues present in the octapeptide repeats $[19,20] . \mathrm{Cu}^{2+}$ modulates synaptic transmission at micromolar concentrations by a wide range of mechanisms, be one of the most relevanting modulations of neurotransmitter receptors within glutamatergic, gabaergic, and purinergic synapses, among others $[43,44]$. In a previous study, we demonstrated that $\mathrm{Cu}^{2+}$ at micromolar concentrations inhibits the ATP-evoked currents of $\mathrm{P}_{2} \mathrm{X}_{4}$ receptors [37]. Here we show that the fulllength prion protein-expressed in Xenopus oocytes localizes in the cell surface and modulates the $\mathrm{Cu}^{2+}$ interaction with $\mathrm{P} 2 \mathrm{X}_{4}$ receptor; oocytes which coexpressed PrP-3F4 and $\mathrm{P} 2 \mathrm{X}_{4}$ receptors have a diminished $\mathrm{Cu}^{2+}$-induced inhibition of the ATP-evoked currents compared with oocytes which only expressed the $\mathrm{P}_{2} \mathrm{X}_{4}$ receptor. This reduced inhibition by $\mathrm{Cu}^{2+}$ was observed on $\mathrm{Cu}^{2+}$ concentration-response curves, where the $\mathrm{IC}_{50}$ of $\mathrm{Cu}^{2+}$ was significantly increased in the presence of PrP-3F4, indicating that PrP-3F4 can exert its modulatory role even at high micromolar concentrations of $\mathrm{Cu}^{2+}$, reached in the synaptic cleft after depolarization [45]. These results, together with our previous findings showing that coapplication of $\mathrm{Cu}^{2+}$ with the $\mathrm{N}$-terminal $\operatorname{PrP}$ fragment $\left(\mathrm{PrP}_{59-91}\right)$ prevents the inhibitory effect of copper on $\mathrm{P}_{2} \mathrm{X}_{4}$ receptors and even reverts the established $\mathrm{Cu}^{2+}$-induced inhibition of the $\mathrm{P}_{2} \mathrm{X}_{4}$ receptors [38], strongly support the idea that $\mathrm{PrP}^{\mathrm{C}}$ could modulate synaptic copper and therefore affect the function of $\mathrm{P}_{2} \mathrm{X}_{4}$ receptors and synaptic transmission.

In addition to the potential synaptic role of $\mathrm{PrPC}^{\mathrm{C}}$ driven by its ability to bind $\mathrm{Cu}^{2+}$, a known modulator of 

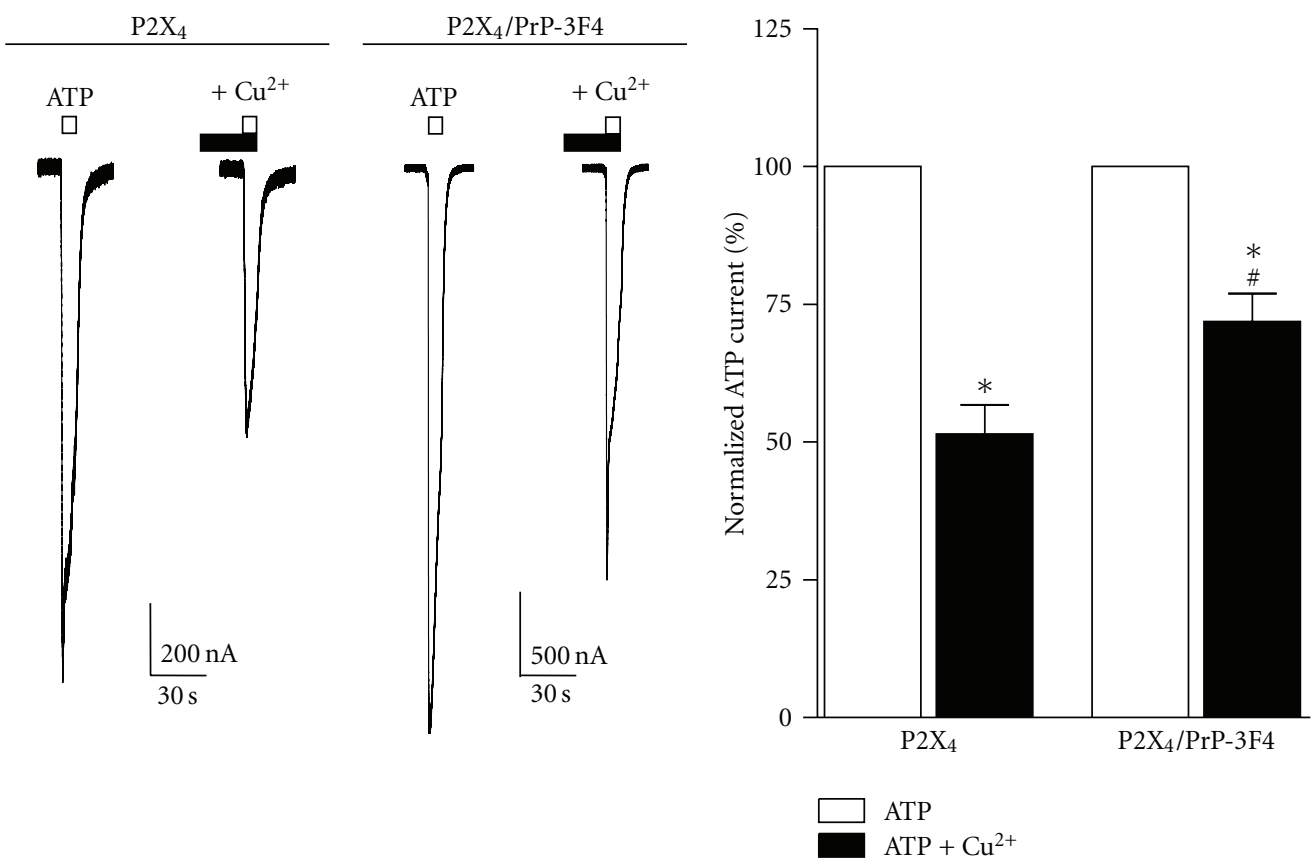

(a)

(b)

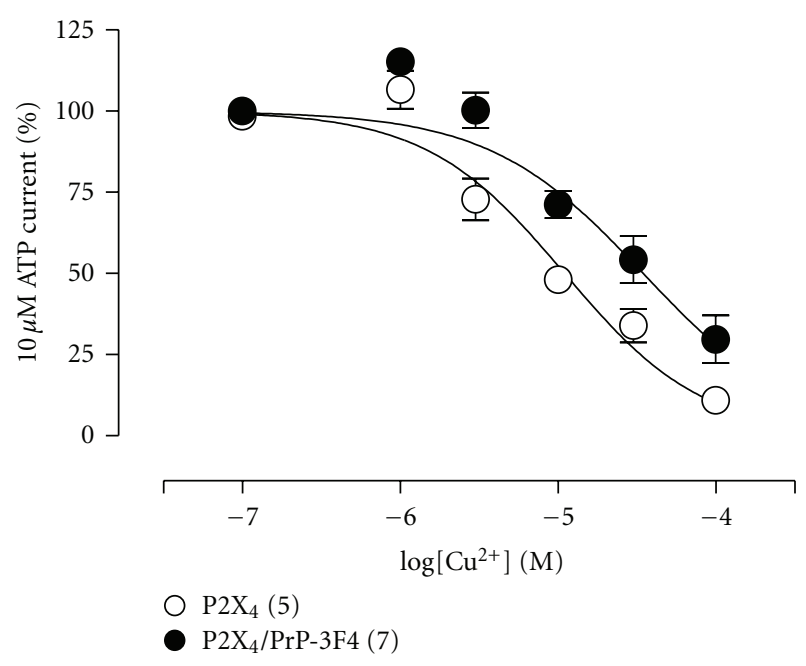

(c)

Figure 3: $\mathrm{PrP}^{\mathrm{C}}$ prevents $\mathrm{Cu}^{2+}$-induced inhibition of $\mathrm{P}_{2} \mathrm{X}_{4}$ receptor. (a) Representative recordings obtained from oocytes expressing $\mathrm{P} 2 \mathrm{X}_{4}$ receptor (left traces, $\mathrm{P}_{2} \mathrm{X}_{4}$ ) or coexpressing $\mathrm{P}_{2} \mathrm{X}_{4}$ receptor and PrP-3F4 (right traces, $\mathrm{P}_{2} \mathrm{X}_{4} / \mathrm{PrP}-3 \mathrm{~F} 4$ ) showing $10 \mu \mathrm{M}$ ATP-evoked currents (open bars) and its inhibition by $10 \mu \mathrm{M} \mathrm{Cu}^{2+}$ (closed bars). (b) Statistical analysis of $\mathrm{Cu}^{2+}$ inhibition showed in (a), performed in different oocytes $\left(n=12-14,{ }^{*} P<0.01\right.$ versus ATP, ${ }^{\#} P<0.01$ versus $\mathrm{P} 2 \mathrm{X}_{4}$ alone). Bars are mean values $\pm \mathrm{SEM}$. (c), Cu ${ }^{2+}$ concentration-response curves of $10 \mu \mathrm{M}$ ATP inhibition in oocytes expressing $\mathrm{P}_{2} \mathrm{X}_{4}$ receptor (open circles) or co-expressing $\mathrm{P} 2 \mathrm{X}_{4}$ receptor and PrP-3F4 (closed circles). Symbols are mean values \pm SEM, numbers in parenthesis are number of oocytes.

neuronal excitability $[43,44]$, there is increasing evidence of direct interaction between $\operatorname{PrP}^{\mathrm{C}}$ and neurotransmitter receptors. $\mathrm{PrP}^{\mathrm{C}}$ directly interacts with the NR2D subunit of the NMDA receptor, inhibiting it and preventing NMDAinduced excitoxicity in the hippocampus [46]. On the other hand, $\operatorname{PrP}^{\mathrm{C}}$ also exerts a neuroprotective role against kainateinduced neurotoxicity in the hippocampus, probably by regulating differentially the expression of GluR6 and GluR7 kainate receptor subunits [47]. Moreover, $\mathrm{PrP}^{\mathrm{C}}$ can modulate the activity of serotoninergic receptors signaling pathways in $1 \mathrm{C} 11^{5-\mathrm{HT}}$ cells [48]. We observed a slight, although not significant, reduction on ATP affinity of $\mathrm{P}_{2} \mathrm{X}_{4}$ receptor in the presence of $\mathrm{PrP}-3 \mathrm{~F} 4$, this might suggest an interference with ATP binding or stabilization of closed states, although further experiments are required to evaluate this hypothesis. Altogether, these studies and the presented here highlight the modulatory role of $\mathrm{PrP}^{\mathrm{C}}$ at synaptic transmission in CNS, involving direct regulation of neurotransmitter receptors 
and/or their signaling cascade, or indirectly, by controlling the synaptic levels of $\mathrm{Cu}^{2+}$.

The understanding of the physiological function of $\operatorname{PrP}^{\mathrm{C}}$ on synaptic transmission may clarify the pathogenic processes underlying prion diseases. Based on our results, it is possible to suggest that the resulting cognitive deterioration of prion diseases could involve a loss of the modulatory role of $\operatorname{PrP}^{\mathrm{C}}$ on brain function, as it is converted to the pathogenic isoform.

\section{Abbreviations}

$$
\begin{aligned}
& \mathrm{PrP}^{\mathrm{C}} \text { : Cellular prion protein } \\
& \text { ATP: Adenosine triphosphate } \\
& \mathrm{CNS} \text { : Central nervous system } \\
& \mathrm{EC}_{50}: \text { Median effective concentration } \\
& \mathrm{IC}_{50} \text { : Median inhibitory concentration. }
\end{aligned}
$$

\section{Acknowledgments}

The authors would like to thank Dr. Claudio Soto (Department of Neurology, The University of Texas Medical School, Tex, USA) for his kind gift of the PrP-GFP construct, and Dr. Richard Kascsak (New York State Institute for Basic Research, Staten Island, NY, USA) for mouse anti-3F4 antibody. This work was supported by Basal Center of Excellence in Aging and Regeneration (CONICYT-PFB12/2007). Ramón A. Lorca is currently with Department of Obstetrics and Gynecology, Center for Women's Reproductive Sciences Research, BJC Institute of Health, Washington University in St. Louis, St. Louis, MO, USA.

\section{References}

[1] S. B. Prusiner, "Prions," Proceedings of the National Academy of Sciences of the United States of America, vol. 95, no. 23, pp. 13363-13383, 1998.

[2] K. M. Pan, M. Baldwin, J. Nguyen et al., "Conversion of $\alpha$-helices into $\beta$-sheets features in the formation of the scrapie prion proteins," Proceedings of the National Academy of Sciences of the United States of America, vol. 90, no. 23, pp. 10962-10966, 1993.

[3] B. Caughey and G. J. Raymond, "The scrapie-associated form of $\mathrm{PrP}$ is made from a cell surface precursor that is both protease- and phospholipase-sensitive," Journal of Biological Chemistry, vol. 266, no. 27, pp. 18217-18223, 1991.

[4] H. A. Kretzschmar, S. B. Prusiner, L. E. Stowring, and S. J. DeArmond, "Scrapie prion proteins are synthesized in neurons," American Journal of Pathology, vol. 122, no. 1, pp. $1-5,1986$.

[5] M. Moser, R. J. Colello, U. Pott, and B. Oesch, "Developmental expression of the prion protein gene in glial cells," Neuron, vol. 14, no. 3, pp. 509-517, 1995.

[6] S. Mouillet-Richard, M. Ermonval, C. Chebassier et al., "Signal transduction through prion protein," Science, vol. 289, no. 5486, pp. 1925-1928, 2000.

[7] X. Roucou, M. Gains, and A. C. LeBlanc, "Neuroprotective Functions of Prion Protein," Journal of Neuroscience Research, vol. 75, no. 2, pp. 153-161, 2004.
[8] N. Vassallo and J. W. Herms, "Cellular prion protein function in copper homeostasis and redox signalling at the synapse," Journal of Neurochemistry, vol. 86, no. 3, pp. 538-544, 2003.

[9] J. Herms, T. Tings, S. Gall et al., "Evidence of presynaptic location and function of the prion protein," Journal of Neuroscience, vol. 19, no. 20, pp. 8866-8875, 1999.

[10] J. Collinge, M. A. Whittington, K. C. L. Sidle et al., "Prion protein is necessary for normal synaptic function," Nature, vol. 370, no. 6487, pp. 295-297, 1994.

[11] L. Varela-Nallar, A. González, and N. C. Inestrosa, "Role of copper in prion diseases: deleterious or beneficial?" Current Pharmaceutical Design, vol. 12, no. 20, pp. 2587-2595, 2006.

[12] M. P. Hornshaw, J. R. McDermott, J. M. Candy, and J. H. Lakey, "Copper binding to the N-terminal tandem repeat region of mammalian and avian prion protein: structural studies using synthetic peptides," Biochemical and Biophysical Research Communications, vol. 214, no. 3, pp. 993-999, 1995.

[13] T. Miura, A. Hori-i, and H. Takeuchi, "Metal-dependent $\alpha$ helix formation promoted by the glycine-rich octapeptide region of prion protein," FEBS Letters, vol. 396, no. 2-3, pp. 248-252, 1996.

[14] D. R. Brown, K. Qin, J. W. Herms et al., "The cellular prion protein binds copperin vivo," Nature, vol. 390, no. 6661, pp. 684-687, 1997.

[15] J. H. Viles, F. E. Cohen, S. B. Prusiner, D. B. Goodin, P. E. Wright, and H. J. Dyson, "Copper binding to the prion protein: structural implications of four identical cooperative binding sites," Proceedings of the National Academy of Sciences of the United States of America, vol. 96, no. 5, pp. 2042-2047, 1999.

[16] J. Stöckel, J. Safar, A. C. Wallace, F. E. Cohen, and S. B. Prusiner, "Prion protein selectively binds copper(II) ions," Biochemistry, vol. 37, no. 20, pp. 7185-7193, 1998.

[17] R. M. Whittal, H. L. Ball, F. E. Cohen, A. L. Burlingame, S. B. Prusiner, and M. A. Baldwin, "Copper binding to octarepeat peptides of the prion protein monitored by mass spectrometry," Protein Science, vol. 9, no. 2, pp. 332-343, 2000.

[18] J. D. F. Wadsworth, A. F. Hill, S. Joiner, G. S. Jackson, A. R. Clarke, and J. Collinge, "Strain-specific prion-protein conformation determined by metal ions," Nature Cell Biology, vol. 1, no. 1, pp. 55-59, 1999.

[19] C. Opazo, M. Inés Barría, F. H. Ruiz, and N. C. Inestrosa, "Copper reduction by copper binding proteins and its relation to neurodegenerative diseases," BioMetals, vol. 16, no. 1, pp. 91-98, 2003.

[20] F. H. Ruiz, E. Silva, and N. C. Inestrosa, "The N-terminal tandem repeat region of human prion protein reduces copper: role of tryptophan residues," Biochemical and Biophysical Research Communications, vol. 269, no. 2, pp. 491-495, 2000.

[21] C. S. Burns, E. Aronoff-Spencer, G. Legname et al., "Copper coordination in the full-length, recombinant prion protein," Biochemistry, vol. 42, no. 22, pp. 6794-6803, 2003.

[22] G. S. Jackson, I. Murray, L. L. P. Hosszu et al., "Location and properties of metal-binding sites on the human prion protein," Proceedings of the National Academy of Sciences of the United States of America, vol. 98, no. 15, pp. 8531-8535, 2001.

[23] K. Qin, Y. Yang, P. Mastrangelo, and D. Westaway, "Mapping $\mathrm{Cu}$ (II) binding sites in prion proteins by diethyl pyrocarbonate modification and matrix-assisted laser desorption ionizationtime of flight (MALDI-TOF) mass spectrometric footprinting," Journal of Biological Chemistry, vol. 277, no. 3, pp. 19811990, 2002.

[24] C. E. Jones, S. R. Abdelraheim, D. E. Brown, and J. H. Viles, "Preferential $\mathrm{Cu}^{2+}$ coordination by His96 and His 111 induces 
$\beta$-sheet formation in the unstructured amyloiodogenic region of the prion protein," Journal of Biological Chemistry, vol. 279, no. 31, pp. 32018-32027, 2004.

[25] J. G. Fournier, F. Escaig-Haye, T. B. De Villemeur, and O. Robain, "Ultrastructural localization of cellular prion protein $(\mathrm{PrPc})$ in synaptic boutons of normal hamster hippocampus," Comptes Rendus de l'Academie des Sciences, vol. 318, no. 3, pp. 339-344, 1995.

[26] N. Sales, K. Rodolfo, R. Hassig, B. Faucheux, L. Di Giamberardino, and K. L. Moya, "Cellular prion protein localization in rodent and primate brain," European Journal of Neuroscience, vol. 10, no. 7, pp. 2464-2471, 1998.

[27] Y. Bailly, A. M. Haeberlé, F. Blanquet-Grossard et al., "Prion protein $(\mathrm{PrPc})$ immunocytochemistry and expression of the green fluorescent protein reporter gene under control of the bovine PrP gene promoter in the mouse brain," Journal of Comparative Neurology, vol. 473, no. 2, pp. 244-269, 2004.

[28] M. A. Chishti, R. Strome, G. A. Carlson, and D. Westaway, "Syrian hamster prion protein $(\operatorname{PrP}(\mathrm{c})$ is expressed in photoreceptor cells of the adult retina," Neuroscience Letters, vol. 234, no. 1, pp. 11-14, 1997.

[29] V. Ralevic and G. Burnstock, "Receptors for purines and pyrimidines," Pharmacological Reviews, vol. 50, no. 3, pp. 413492, 1998.

[30] R. Kanjhan, G. D. Housley, L. D. Burton et al., "Distribution of the $\mathrm{P} 2 \mathrm{X}_{2}$ receptor subunit of the ATP-gated ion channels in the rat central nervous system," Journal of Comparative Neurology, vol. 407, no. 1, pp. 11-32, 1999.

[31] W. Norenberg and P. Illes, "Neuronal P2X receptors: localisation and functional properties," Naunyn-Schmiedeberg's Archives of Pharmacology, vol. 362, no. 4-5, pp. 324-339, 2000.

[32] M. E. Rubio and F. Soto, "Distinct localization of P2X receptors at excitatory postsynaptic specializations," Journal of Neuroscience, vol. 21, no. 2, pp. 641-653, 2001.

[33] R. A. Lorca, C. Rozas, S. Loyola et al., "Zinc enhances longterm potentiation through $\mathrm{P} 2 \mathrm{X}$ receptor modulation in the hippocampal CA1 region," European Journal of Neuroscience, vol. 33, no. 7, pp. 1175-1185, 2011.

[34] R. Cloues, S. Jones, and D. A. Brown, " $\mathrm{Zn}^{2+}$ potentiates ATPactivated currents in rat sympathetic neurons," Pflugers Archiv, vol. 424, no. 2, pp. 152-158, 1993.

[35] C. Li, R. W. Peoples, Z. Li, and F. F. Weight, " $\mathrm{Zn}^{2+}$ potentiates excitatory action of ATP on mammalian neurons," Proceedings of the National Academy of Sciences of the United States of America, vol. 90, no. 17, pp. 8264-8267, 1993.

[36] K. Xiong, R. W. Peoples, J. P. Montgomery et al., "Differential modulation by copper and zinc of $\mathrm{P}_{2} \mathrm{X}_{2}$ and $\mathrm{P} 2 \mathrm{X}_{4}$ receptor function," Journal of Neurophysiology, vol. 81, no. 5, pp. 20882094, 1999.

[37] C. Acuña-Castillo, B. Morales, and J. P. Huidobro-Toro, "Zinc and copper modulate differentially the $\mathrm{P}_{2} \mathrm{X}_{4}$ receptor," Journal of Neurochemistry, vol. 74, no. 4, pp. 1529-1537, 2000.

[38] R. A. Lorca, M. Chacón, M. I. Barría, N. C. Inestrosa, and J. P. Huidobro-Toro, "The human prion octarepeat fragment prevents and reverses the inhibitory action of copper in the $\mathrm{P}_{2} \mathrm{X}_{4}$ receptor without modifying the zinc action," Journal of Neurochemistry, vol. 85, no. 3, pp. 709-716, 2003.

[39] J. G. Connolly, R. J. Tate, N. F. McLennan et al., "Properties of the cellular prion protein expressed in Xenopus oocytes," NeuroReport, vol. 13, no. 9, pp. 1229-1233, 2002.

[40] R. J. Kascsak, R. Rubenstein, P. A. Merz et al., "Mouse polyclonal and monoclonal antibody to scrapie-associated fibril proteins," Journal of Virology, vol. 61, no. 12, pp. 3688 3693, 1987.
[41] A. Aguzzi, F. Baumann, and J. Bremer, "The prion's elusive reason for being," Annual Review of Neuroscience, vol. 31, pp. 439-477, 2008.

[42] J. W. Herms, H. A. Kretzschmar, S. Titz, and B. U. Keller, "Patch-clamp analysis of synaptic transmission to cerebellar purkinje cells of prion protein knockout mice," European Journal of Neuroscience, vol. 7, no. 12, pp. 2508-2512, 1995.

[43] J. P. Huidobro-Toro, R. A. Lorca, and C. Coddou, "Trace metals in the brain: allosteric modulators of ligand-gated receptor channels, the case of ATP-gated P2X receptors," European Biophysics Journal, vol. 37, no. 3, pp. 301-314, 2008.

[44] A. Mathie, G. L. Sutton, C. E. Clarke, and E. L. Veale, "Zinc and copper: pharmacological probes and endogenous modulators of neuronal excitability," Pharmacology and Therapeutics, vol. 111, no. 3, pp. 567-583, 2006.

[45] J. Kardos, I. Kovacs, F. Hajos, M. Kalman, and M. Simonyi, "Nerve endings from rat brain tissue release copper upon depolarization. A possible role in regulating neuronal excitability," Neuroscience Letters, vol. 103, no. 2, pp. 139-144, 1989.

[46] H. Khosravani, Y. Zhang, S. Tsutsui et al., "Prion protein attenuates excitotoxicity by inhibiting NMDA receptors," Journal of Cell Biology, vol. 181, no. 3, pp. 551-555, 2008.

[47] A. Rangel, F. Burgaya, R. Gavín, E. Soriano, A. Aguzzi, and J. A. Del Río, "Enhanced susceptibility of Prnp-deficient mice to kainate-induced seizures, neuronal apoptosis, and death: role of AMPA/kainate receptors," Journal of Neuroscience Research, vol. 85, no. 12, pp. 2741-2755, 2007.

[48] S. Mouillet-Richard, M. Pietri, B. Schneider et al., "Modulation of serotonergic receptor signaling and cross-talk by prion protein," Journal of Biological Chemistry, vol. 280, no. 6, pp. 4592-4601, 2005. 


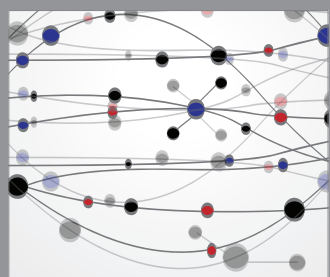

The Scientific World Journal
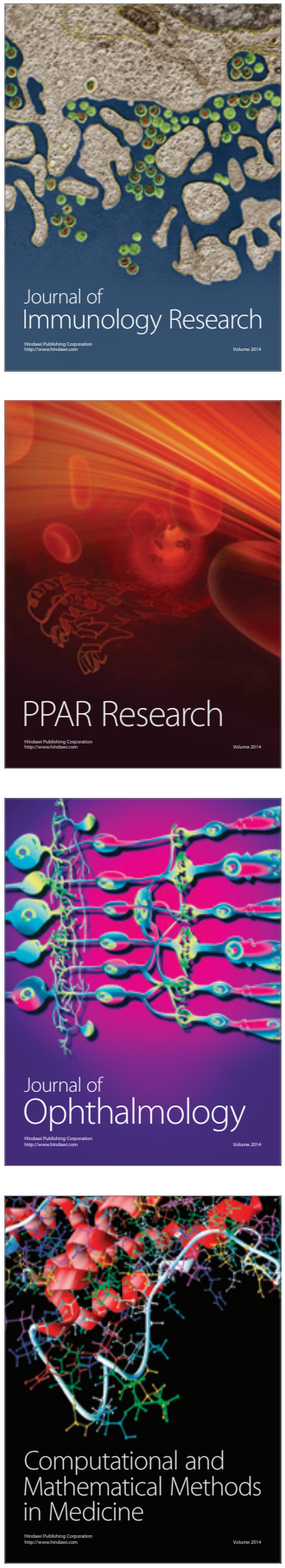

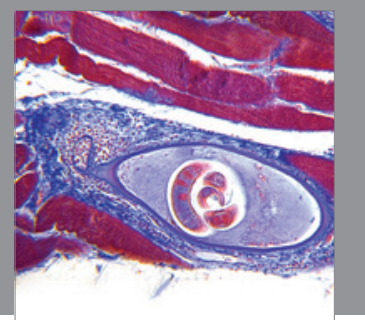

Gastroenterology

Research and Practice
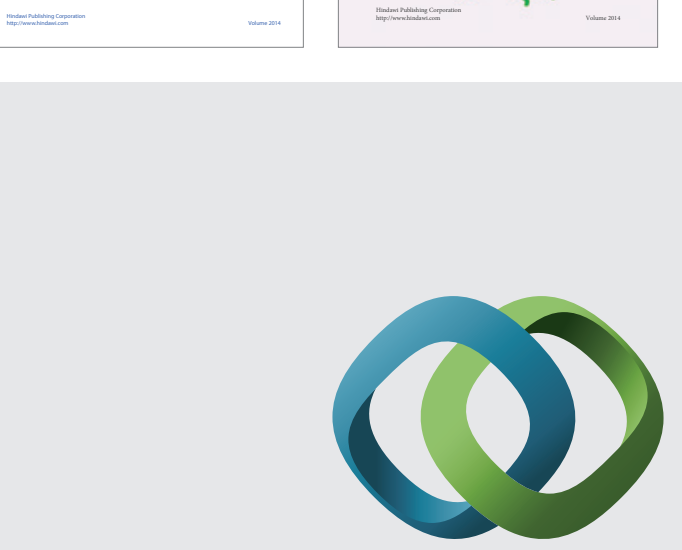

\section{Hindawi}

Submit your manuscripts at

http://www.hindawi.com
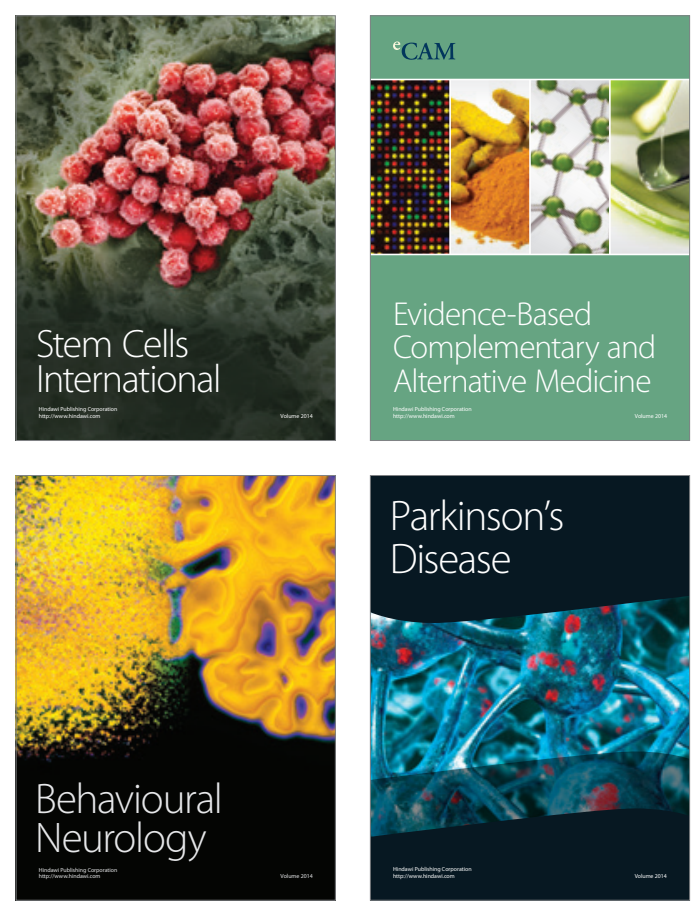

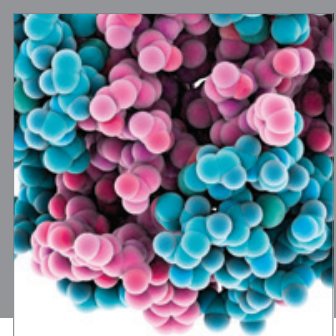

Journal of
Diabetes Research

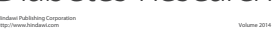

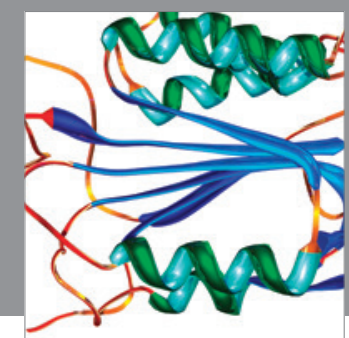

Disease Markers
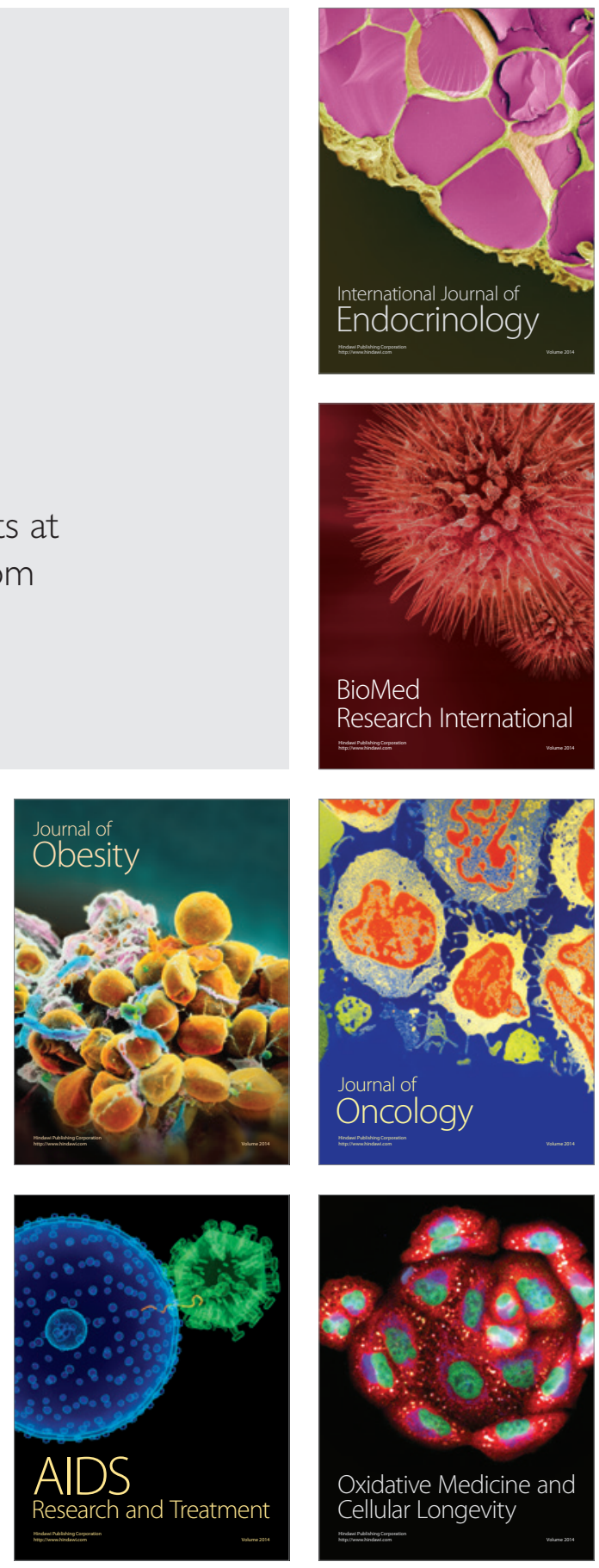